Choat, Simon (2019) The iron cage of enterprise or the restoration of class power? Approaches to understanding neoliberalism. Political Studies Review, 17(4), pp. 416-427. Copyright @ 2019 (The Author). Reprinted by permission of SAGE Publications. 


\section{The iron cage of enterprise or the restoration of class power? Approaches to}

\section{understanding neoliberalism}

\section{$\underline{\text { Introduction }}$}

If the concept of neoliberalism can seem elusive, it is not only because it has been applied to an enormous range of political, social, and economic phenomena, but also because it has been employed within a bewildering array of theoretical frameworks and consequently subjected to a variety of competing and sometimes incompatible definitions. As a result, many commentators and academics are suspicious of the term; some have even advocated its abandonment, on the basis that such an imprecise and promiscuous concept is too unwieldy and ambiguous to be of much use (e.g. Barnett, 2005; Clarke, 2008; Ferguson, 2010; Venugopal, 2015).

That the meaning of 'neoliberalism' is contested, however, hardly makes it atypical among political concepts. The intelligent response to disagreements and confusions over meaning is not to abandon the concept in question, but to evaluate alternative definitions. This article is intended as a contribution to such an evaluation. It will compare two approaches to understanding neoliberalism: a Marxist approach that defines neoliberalism as a class project encompassing both a set of economic policies and the ideology through which those policies are justified and promoted; and a Foucauldian approach that defines neoliberalism as a form of governmentality that installs competition and enterprise as regulatory norms. Although these are not the only available frameworks employed to analyse neoliberalism (see e.g. Birch, 2015; Flew, 2014; Davies, 2014), they are arguably the most common and influential. Whilst there are similarities, and even points of overlap, between the authors that I identify as 'Marxist' and 'Foucauldian', I contend that it is both analytically possible and heuristically valuable to distinguish them. At the same time, the significant disagreements between the two approaches do not mean that the concept of 
neoliberalism is incoherent or that as a social form it does not really exist; nor does it mean that that we have to 'pick sides' by declaring allegiance to one interpretation over the other. Rather, I will argue that Marxist and Foucauldian definitions can and should be used in conjunction with one another to illuminate different aspects of the same phenomenon.

The first section of the article contrasts Marxist and Foucauldian approaches by offering a brief summary of their basic claims. As well as the classic interpretation by David Harvey (2005), I also draw on various other Marxist accounts published in the wake of the 2008 financial crisis (especially Albo et al., 2010; Callinicos, 2010; Duménil and Lévy, 2011; Hall, 2011; Kotz, 2015). Rather than directly addressing Foucault's (2008) own lectures, I will take as exemplary of the Foucauldian approach recent applications of his theoretical framework, specifically works by Pierre Dardot and Christian Laval (2013), Wendy Brown (2015), and Béatrice Hibou (2015). Hence, when I use the term 'Foucauldian' I am referring specifically to these writers, all of whom make use of Foucault's concepts and arguments to interrogate contemporary neoliberal practices, while simultaneously going beyond Foucault to develop and further his insights. ${ }^{i}$ The designation is not, therefore, intended to suggest complete fidelity to Foucault's methodology, nor overt agreement with his findings, but rather to indicate work produced within parameters initially set by Foucault. ${ }^{\text {ii }}$

The second section identifies the strengths of the Foucauldian approach, which I take to be their disclosure of the novelty of neoliberalism and its production of bureaucratic norms and entrepreneurial modes of subjectivity. In the next two sections I outline the weaknesses of the Foucauldian approach - primarily its tendency to present neoliberalism as an inescapable and monolithic 'iron cage' - and offer a qualified defence of Marxism, arguing that it is hard to make sense of neoliberalism without taking into account the interests which it serves. I conclude by claiming that despite significant differences between the two frameworks, they are nevertheless compatible, and to understand neoliberalism we require a Marxist-Foucauldian approach. 


\section{Contrasting Marxist and Foucauldian interpretations of neoliberalism}

Broadly speaking, Marxists and Foucauldians agree that 'neoliberalism' refers to the extension of the market to cover all social relations. But they disagree, first, about the origins and agents of neoliberal marketization. Marxists depict neoliberalism as the ruling class's response to the social and economic crises of the 1970s: it began as a 'counterrevolution' (Glyn, 2006: 24) or political project whose aim was to reassert the power of capital over labour and reverse the declining rate of profit (Harvey, 2005; Van Apeldoorn and Overbeek, 2012: 4; Albo et al., 2010: 27). This aim was pursued through the ending of the 'class compromise' (Harvey, 2005: 10) of the period 1945-73 and the dismantling of its social-democratic and Keynesian regulations and protections. Neoliberalism for Marxists thus entails the 'general commercialization of social relations' (Duménil and Lévy, 2004: 2) or 'the commodification of everything' (Harvey, 2005: 165). Its agents and beneficiaries have been the ruling class, especially finance capital (Duménil and Lévy, 2004), and their success has come at the expense of labour (Harvey, 2005: 76).

For Foucauldians, this understanding of neoliberalism as a class project is reductively economistic (Dardot and Laval, 2013: 9-11). Rather than being planned and implemented by a sovereign subject ('the ruling class'), neoliberalism has diffuse origins: its causes are complex and heterogeneous, and it is a result of a plurality of 'intentionalities and nonintentionalities' (Hibou, 2015: xix). Neoliberalism is not, according to Foucauldians, a political project, but a form of governmentality (Dardot and Laval, 2013) or a governing rationality (Brown, 2015): a set of techniques for conducting the conduct of subjects (cf. Foucault, 2008: 186). While they accept that - as the dissemination of market values neoliberalism can be understood as a form of 'economization', Foucauldians insist that this is not to be understood in narrowly economistic terms, because it does not necessarily involve the literal marketization or monetization of spheres of life. Brown (2015: 31, 230n33) 
uses the example of dating: although neoliberalism encourages us to understand and conduct our love lives in economic terms - investing time and energy in the hope of a return, increasing our efficiency and productivity through dating apps, 'outsourcing' the search for love to matchmaking websites, and so forth - the aim of this conduct is not literally to make a monetary profit. Neoliberalism involves the imposition of market norms rather than the submission of all activity to the profit motive, and so cannot be seen simply as serving the economic interests of the bourgeoisie.

Second, there is disagreement between the two approaches over the role of the neoliberal state. The focus of Marxist analyses of neoliberalism tends to be on policies which involved the withdrawal of the state: deregulation of the financial sector and of consumer and employment protections, retreat of government intervention through privatisations, cutting taxes and welfare, removal of barriers to free trade and the international mobility of capital (cf. Glyn, 2006; Kotz, 2015). Nonetheless, most Marxists insist that the neoliberal rhetoric of the minimal state is ultimately obfuscatory, serving to mask neoliberalism's dependence upon the state (to establish and regulate markets, bail out banks, crush dissent, etc.) (e.g. Harvey, 2005: 70-81; Albo et al., 2010: 35). They argue that the macroeconomic management of postwar social democracy has not been abandoned so much as reconfigured towards different ends (Callinicos, 2010: 69; cf. Duménil and Lévy, 2011: 88). For Foucauldians, however, this recognition of the interventionist nature of the neoliberal state does not go far enough: it simply restates the Marxist belief that capital needs the state to defend and augment its interests, and does not recognise the radical transformation of the state wrought by neoliberalism. This transformation, Foucauldians argue, is in part based on neoliberalism's novel understanding of the market. For classical liberalism, the market was a spontaneously occurring sphere of exchange between equal individuals, rooted in the human 'propensity to truck, barter, and exchange' (Smith, 1976: 25): consequently, the role of the state was to let the market function and to compensate 
for its deficiencies or pernicious effects (e.g. by providing education). In contrast, for neoliberals the market is necessarily constructed and its essence is not exchange between individuals but competition between enterprises, premised upon and productive of inequality (Dardot and Laval, 2013: 301; Brown, 2015: 62-66; cf. Foucault, 2008: 118). Because competition is not 'a primitive and natural given', the state must constantly intervene in order to establish and guarantee the conditions of competition - to construct what is not given by nature (Foucault, 2008: 131). Hence, for neoliberalism the ideal is not the minimal state but the entrepreneurial state: the market is the principle 'not of the state's limitation, but of its internal regulation from start to finish of its existence and action' (Foucault, 2008: 116; cf. Dardot and Laval, 2013: 16-18). This means that the state has legitimacy only insofar as it promotes and protects market competition, but also that the state is itself submitted to market criteria (Brown, 2015: 63-64; cf. Foucault, 2008: 246-7). There is a marketization of the state, with the state viewed as one enterprise among many (Dardot and Laval, 2013: 216-8). State functions are not necessarily privatised, but must be performed according to the norms of private enterprise: policies and their execution are judged according to whether or not they are cost-effective, efficient, productive, etc. Because the efficiency of government activities and institutions must be monitored, there is a 'bureaucratic inflation' of regulatory bodies whose task is to audit and evaluate performance through the use of targets, objectives, metrics, etc. (Dardot and Laval, 2013: 250; Hibou, 2015).

Finally, there is disagreement about the role and status of neoliberal discourse. For Marxists, neoliberal theory is pure ideology: it reflects and justifies, rather than motivates or shapes, neoliberal practice. Its rhetoric of individual freedom and autonomy merely disguises the reality of class domination. This does not mean, however, that neoliberal theory is superfluous or disposable, for it is argued that it plays an important role in 
constructing neoliberalism as common sense and hence winning support for and consent to the neoliberal project (Hall, 2011; Harvey, 2005: 39-63; Van Apeldoorn and Overbeek, 2012).

For Foucauldians, in contrast, the neoliberal discourse of freedom, choice, individual responsibility, etc. is constitutive rather than illusory: neoliberalism governs through and on the basis of individual freedom. In place of the direct subjugation or domination of subjects, it constitutes entrepreneurial subjects who are afforded the freedom to act in accordance with the rationality of the market. 'Neoliberal subjects are controlled through their freedom' (Brown, 2005: 44). This is 'government at a distance': individuals are given personal responsibility, but only on the basis that they engage in a self-monitoring of their action within a framework of particular rules and norms (Hibou, 2015: 68). Because the 'rational' functioning of the market and its actors is not assured by nature, appropriate types of thinking and behaviour must be induced. This is why there is an inflation of bureaucracy under neoliberalism: processes, institutions, and actors must be monitored, audited, evaluated, and certified, to ensure that they are efficient, cost-effective, transparent, and accountable and that the market operates as it should. If people accede to neoliberalism, therefore, it is not because they are deceived by a set of ideas that conceal reality, but because in their everyday practices they actively participate in and recreate neoliberal techniques of governing. Hence our analysis should focus not on policies or ideas that are imposed from above, but on the attitudes and practices that make up what Philip Mirowski (2014: 92) - some of whose arguments resonate with those of the Foucauldian critics here under consideration - calls 'everyday neoliberalism'. iii

\section{Advantages of the Foucauldian approach}

The Foucauldian writers cited above are all in different ways and to differing degrees critical of Foucault (e.g. Brown, 2015: 73-111; Hibou, 2015: 16-17). But they can all reasonably be named 'Foucauldian' on the basis that their analyses of neoliberalism all follow Foucault in: 
shifting the focus of study from the state to technologies of government; insisting that those technologies of government be understood in terms of their underlying rationality; and emphasising the novelty of neoliberal rationality, centred around the figure of the enterprise. Hence, while not all of these authors would call themselves Foucauldian - and might even reject that label - none of their analyses would have been possible without The Birth of Biopolitics: they are 'Foucauldian' not because they agree with everything Foucault said or merely repeat his claims, but because they seize on and put to work the central and distinctive insights of his work on neoliberalism.

Perhaps above all, they are distinctively Foucauldian in the sense that they share a common critique of the Marxist approach to neoliberalism. This is true even of Brown, who acknowledges the significance of Marx's analysis of capitalism to understanding neoliberalism while nonetheless using Foucault to highlight Marxism's inability to grasp neoliberalism's singular characteristics (e.g. Brown, 2005: 45). Indeed, the Foucauldian critique can be summarised by saying that they argue that Marxism underplays the novelty of neoliberalism. This is in many respects a legitimate and convincing claim. Various Marxists have framed neoliberalism as the re-emergence of 'an old form of capitalism', characterised by the return of market forces, the restoration of ruling class power, the reassertion of the hegemony of finance capital, and a resurgence of income inequality (Kotz, 2015: 46; Duménil and Lévy, 2004; Glyn, 2006). For Foucauldians, this emphasis on continuity and repetition underestimates the way in which neoliberalism, as a political rationality, develops and implements a specific and innovative conception of the market and of the role of the state in relation to the market.

As Foucault (2007: 109) himself has suggested, by reducing the state to the function of reproducing capitalist relations of production, Marxism tends ironically to inflate its importance: it 'makes the state absolutely essential as the target to be attacked'. In contrast, the concept of governmentality allows Foucauldians to separate 'government' from 'the 
state', and in doing so to stress the originality of neoliberalism. They can show that the retreat of the state under neoliberalism is real, and not (pace Marxism) an ideological smokescreen, but that this retreat has been accompanied by an explosion of techniques of government. To reverse a formulation from Foucault (2008: 102), neoliberalism gives us more government with less state. The state has withdrawn from the direct provision of goods and services but only by establishing markets which require constant intervention and governance to function. While individuals are given freedom and responsibility for their choices, those free individuals must be guided and induced to act in 'rational' ways. Because markets are constructed rather than natural, market rationality must be imposed. This is why there is an increase in governmental bureaucracy: it is through various forms of auditing, monitoring, and ranking that the 'rational' and efficient functioning of the market is assessed and assured and individuals are encouraged or constrained to act as rational economic actors. What results is neither simply privatization and the shrinking of the state nor the continued state provision of services by public servants. What we see is a 'hybridization between public and private' in which 'the borders between public and private, and the very meaning of these two notions, are muddled' (Hibou, 2015: 62, 40).

Foucault and his successors thus move beyond or beneath the state to examine techniques of government, arguing that these techniques infiltrate all institutions of society: there is an 'increasing ubiquity of market and business norms', entailing a 'neoliberal bureaucratization of everyday life' (Hibou, 2015: 11, 9). Moreover, the norms and rules through which neoliberalism governs are not so much enforced from above (by the state or by transnational institutions) as embraced from below. Whereas Marxist analyses of neoliberalism focus on loss or destruction (of social solidarities, collective rights, regulations, ways of life, and so on), the Foucauldian analysis focuses on the everyday practices through which neoliberalism produces subjects who willingly adopt neoliberal norms. 
Foucauldians have thus developed what we might call a microphysics of neoliberal power that allows us to trace how neoliberal norms are internalised and enacted, and hence how neoliberalism is sustained and reproduced. This type of analysis is enabled not only by moving beyond the state but also by thinking about what is new in neoliberalism's concept of the market. Foucauldians convincingly argue that rather than simply extending market relations ('the commodification of everything'), neoliberalism redefines the market, now understood in terms of competition between enterprises rather than exchange between individuals: everything, including and especially human beings, is conceived of as an enterprise. Neoliberalism's homo economicus is not the utility maximiser of classical liberalism, but an entrepreneurial self: a unit of human capital whose purpose is to invest in himself in order to increase his value and position himself better in the competitive market (Brown, 2015: 80-87; Dardot and Laval, 2013: 107; cf. Foucault, 2008: 147). By focusing in particular on the individual as entrepreneur and the reconfiguration of the human as human capital, Foucauldians are able to offer an analysis of the quotidian operation of neoliberalism that is far more finely grained and subtle than the Marxist analysis.

Moreover, they can provide a more convincing account of the resilience of neoliberalism. As we have seen, Marxists explain neoliberalism's persistence at least in part by resorting to the Gramscian category of consent, focusing on the construction of neoliberalism as common sense. Yet, especially in the wake of the 2008 financial crisis, neoliberal 'common sense' has been widely challenged and even rejected. Rather than asking how neoliberal ideology aids and advances neoliberal policies, today we must ask why it is that neoliberalism endures even when neoliberal ideology is increasingly viewed as bankrupt. The Foucauldian response is that by looking at bottom-up practices rather than ideas circulated from above then it can be seen that a person may be suspicious of, even hostile towards, neoliberalism while nonetheless actively adopting neoliberal behaviours. Indeed, resistance to neoliberalism can unwittingly take neoliberal forms, as when 
protestors and activists rely on technologies like Twitter and Facebook (which encourage the individual to become her own 'brand') (cf. Mirowski, 2014: 328). In this and many other ways, neoliberalism 'can be intensified by actions that are directly aimed against it' (Hibou, 2015: xviii).

\section{Weaknesses of the Foucauldian approach}

By bringing to light the conception of the entrepreneurial self and its constitution through everyday practices, Foucauldians offer a compelling account not only of neoliberalism's novelty but also of its tenacity and endurance. A central weakness of their work, however, is that they apparently cannot see beyond this tenacity: there is a tendency in Foucauldian analyses to present neoliberal subjectivization as always successful, such that the self becomes nothing more than the effect of neoliberal strategies and practices. This strong strain of Weberian pessimism is explicit in the metaphor of the 'iron cage' that Dardot and Laval (2013: 262) use to describe neoliberal subjectivity (cf. Hibou, 2015: 86; Brown, 2015: 111). Even the opposition and resistance that do exist, it is argued, often inadvertently reinforce neoliberalism and its bureaucracy (Hibou, 2015: 119).

The cynicism of Foucauldian analyses may seem surprising because, on the face of it, it is in sharp contrast to what Foucault himself offers. Although claims that Foucault was a closet neoliberal are ultimately unconvincing, his analysis in The Birth of Biopolitics is notoriously non-judgemental, and in no way does he pose neoliberalism as an inescapable threat or danger. ${ }^{\text {iv }}$ Moreover, the concept of governmentality with which neoliberalism is analysed by Foucault - and which is then taken up by his successors - seems in part designed to preclude the kind of hopelessness that we find in recent applications of his work. As many of its first interpreters argued, 'governmentality' can be understood as moderating Foucault's earlier notion of disciplinary power, which was plausibly criticised for implying that the subject is wholly determined by an all-embracing form of domination. In 
contrast, because it presupposes individual freedom, governmentality suggests a capacity to resist or avoid domination, 'loosening... the connection between subjectification and subjection' (Burchell, 1996: 20; cf. Gordon, 1991: 4-5; McNay, 1994).

Yet for Foucauldian analysts of neoliberalism it is precisely because neoliberal governmentality presupposes and operates through individual autonomy that it is so dominant. The 'freedom to choose' which it accords to individuals is real, but it is conditional on engaging in competitive behaviour and accepting the market as the only 'rules of the game' (Dardot and Laval, 2013: 170). Because neoliberalism relies on self-government, its market norms and the entrepreneurial spirit are not imposed from above or outside but are voluntarily internalised and even actively embraced. This is 'a domination that is all the more powerful for being invisible', 'exercised to a great extent without people realizing it, through self-control and the interiorization of norms' (Hibou, 2015 p. 91).

Their conceptualization of neoliberalism is similar to Foucault's conceptualization of power: not emanating from a single source (such as the power of the bourgeoisie), it is omnipresent, permeating all social relations. But whereas in his discussions of power Foucault (1979: 92) explicitly rules out 'the over-all unity of a domination', for Foucauldians neoliberalism entails that the 'same normative logic' governs all levels of society, giving it 'the incomparable advantage of linking all power relations in the framework of a single discourse' (Dardot and Laval, 2013: 5, 263).

This approach not only depicts neoliberalism as totalizing and inescapable, it also places a very strong emphasis on the rupture with the past that neoliberalism introduces. Dardot and Laval $(2013: 304,305)$ argue that by replacing the figure of the citizen as a bearer of political rights with the figure of entrepreneurial man, 'the whole of citizenship as construed in western countries since the eighteenth century is called into question at its very roots', such that neoliberalism 'heralds a new phase in the history of Western societies'. Brown (2015: 87-99) goes further, arguing that neoliberalism destroys a notion of 
homo politicus that dates back to at least Aristotle. In increasingly heightened language, Brown $(2015: 99,222,188)$ thus claims that neoliberalism is 'revolutionary', a 'civilizational turning point', and risks ushering in the moment when 'humanity will have entered its darkest chapter ever'.

There is no question of 'blaming' Foucault for the pessimism and hyperbole of those who have used his work to analyse neoliberalism. But I think it can nonetheless be said that Foucauldians have extrapolated from tendencies and arguments in Foucault's own work, specifically: his conceptualization of neoliberalism as a form of governmentality that operates by multiplying rather than restricting freedoms; his understanding of power as ubiquitous; and his emphasis on discontinuity and rupture. In Foucauldian analyses of neoliberalism these themes are translated into a theory of neoliberalism as: a form of governmentality that undercuts all potential resistance by basing itself on the very autonomy that would be the source of such resistance; a form of power that is all-pervasive and monolithic; and a turning point in human history that is without precedent. Consequently, what is emphasised in these analyses is the extreme difficulty and improbability of opposing neoliberalism.

In Foucauldian analyses, neoliberalism thus becomes a total, all-encompassing, and virtually uncontested form of domination, as if the neoliberal fantasy of the economization of all social life has actually been realised - as if the real world is indistinguishable from that found in the pages of a Gary Becker book. Some critics have explicitly claimed that Foucault himself is at fault here. Lois McNay (2009: 69), for instance, argues that 'Foucault does not distinguish sufficiently between neoliberalism as a theory which is intellectually hegemonic and a practice of governance which is never assured or complete'. But this is unfair to Foucault, who was writing at a time when neoliberalism 'in practice' was only in its nascent stages and so could have done little other than provide an exegesis of neoliberal texts. At the start of The Birth of Biopolitics he makes clear that his object of study is not practices of 
government but the 'rationalization of governmental practice' or 'government's consciousness of itself' (Foucault, 2008: 2). We should also bear in mind that The Birth of Biopolitics is a lecture series and hence a provisional outline rather than a completed project. Given Foucault's justifiable focus on theoretical writings, one of the ways in which Foucauldians distinguish their own analyses is by turning their attention to neoliberal practices. While this is a legitimate and laudable aim, however, it is pursued as if those practices are the seamless realisation of neoliberal reason.

\section{Revisiting Marxism}

Conceiving of neoliberalism as a governing rationality certainly has its advantages: it allows Foucauldians to view neoliberal reason as constitutive rather than simply as a set of ideas which are reflective of, or which are used to disguise, pre-existing practices. But it also leads them to overstate the coherence and uniformity of neoliberal reason and the ease and success with which it has been implemented and realised. Conversely, although Marxists tend to be blind to the specific novelty of neoliberal rationality and its constitutive role, their conception of neoliberalism as a set of economic policies and its ideology helps challenge the apparent invincibility of neoliberalism. Somewhat ironically, given Foucauldian accusations of the reductiveness of Marxism, Marxists have been far more attentive to the complex and uneven development of neoliberalism and the diverse forms and paths which it has taken. Rather than seeing neoliberalism as a successfully realized form of reason, Marxists have argued that neoliberalism is articulated in ambiguous and diverse ways: there are contradictions and tensions within and between neoliberal theory and practice (cf. Hall, 2011: 713; Harvey, 2005: 64-81). As such, although neoliberalism is dominant, it is more unstable and fragile than Foucauldians allow. This instability arises in part from the specific policies that neoliberalism advances: in its pursuit of profits and high incomes at the expense of investment, it is increasingly reliant on debt, bubbles, and complex and risky 
financial innovations and hence is highly volatile and prone to crises (Duménil and Lévy,

2011: 22-25; Callinicos, 2010: 50-83).

Conceptualizing neoliberalism as a project that serves the interests of a certain social group - namely the ruling class, especially finance capital - further allows Marxists to stress the opposition that neoliberalism faces from other social groups and hence the setbacks and reversals to which it is subject. In contrast to the Foucauldian tendency to frame neoliberalism as monolithic and totalizing, Marxists present neoliberalism as a process (Hall, 2011: 727) or a 'project in motion, continuously contested, a process of countless rounds of struggles and negotiations with oppositional forces' (Van Apeldoorn and Overbeek, 2012: 6). Although there are Foucauldians who emphasise the ambiguous, indeterminate, and contested nature of neoliberalism (cf. Hibou, 2015), this stress on the polyvalence and heterogeneity of neoliberal discourses and techniques tends to obscure the actual power dynamics at operation within neoliberalism and the sharp divisions it has produced and exacerbated. What is foregrounded by Foucauldians is our mutual complicity in neoliberalism and consequently our equal ability to engage in practices of microresistance. But this is to downplay the highly asymmetric nature of neoliberal power relations and their differential and polarizing effects.

Presenting neoliberalism as a form of political rationality not only marginalises analysis of the distributive effects of neoliberalism, it is also one-sided. It is at best partial to claim, as Foucauldians do, that neoliberalism requires the imposition of market rationality but not necessarily the imposition of markets as such. To return to an earlier example: we saw that Brown claims that while we are called upon to think of sexual relationships in economic terms, we are not literally required to monetize our love lives - hence economization does not equal monetization. But Brown's example undermines her own point, because the world of dating obviously is highly monetized: it is a multi-billion dollar global industry and we are encouraged to think of our love lives in economic terms by the 
various dating companies, websites, and apps whose aim is precisely to make a monetary profit. In other words, the expansion of neoliberal rationality into the realms of sex and love serves a higher end, namely that of profitability.

It may be that Brown's example is simply poorly chosen, but it is hard to think of any instance of the imposition of market rationality that does not have increased profitability as its ultimate goal. This does not mean that the Foucauldian approach is irrelevant: to the contrary, it is extremely valuable for analysing the specific modes of reason and subjectivity that marketization involves. But the analysis will be incomplete if it does not acknowledge that marketization produces a certain distribution of wealth that benefits particular economic interests.

\section{A Marxist-Foucauldian approach}

Unless we recognise that particular interests have been served by neoliberalism, it is hard to see why it has been a specifically neoliberal mode of reason that has triumphed.

Foucauldians, as we have seen, account for the success of neoliberalism by pointing to our complicity or active participation: through their free choices, neoliberal subjects govern themselves in accordance with the rationality of the market. But why the specifically economic rationality of the market? Why not some other form of rationality? For Marxists, the answer is relatively straightforward: it is because, ultimately, it serves the interests of capital. As Duménil \& Lévy (2004: 128-139) ask: 'Who benefits from the crime?' Their answer is that '[f]inance benefitted', and so we must see finance capital as the architect and agent of neoliberalism. For Foucauldians, this is likely to appear too teleological, for it implies that one of the results of neoliberalism (increased wealth and power for capital) can explain the whole phenomenon, as if neoliberalism was carefully planned by a conscious agent with clear goals in mind. It is for this reason that Dardot and Laval (2013: 8) argue that 
Duménil \& Lévy's question - 'Who benefits from the crime?' - is poorly put: it reflects 'a recurrent fallacy, which consists in identifying the beneficiary of a crime with its author'.

Yet Duménil \& Lévy (2004: 212) are more subtle than Dardot and Laval allow: they explicitly state that the question of the results and beneficiaries of neoliberalism is not identical to the question of how exactly we arrived at neoliberalism, claiming that '[n]eoliberalism has developed as the product of a whole range of processes'. In other words, conceptualising neoliberalism as a political project that benefits the ruling class does not necessarily mean viewing it as the product of a conspiracy or perfectly executed plan. As Harvey (2005: 13) has put it, '[t]he capitalist world stumbled towards neoliberalization... through a series of gyrations and chaotic experiments'. It is possible to acknowledge the multifaceted origins of neoliberal techniques whilst nonetheless simultaneously recognising that those techniques and policies have been adopted by a particular class and used for their own ends. Indeed, something like this approach has been used by Foucault (1980: 101) himself, who in various contexts has shown how different discourses, apparatuses of power, and disciplinary techniques have been adopted by the bourgeoisie and put to 'economically advantageous and politically useful' ends.

In short, rather than viewing the Marxist and Foucauldian approaches to neoliberalism as incompatible alternatives (cf. Flew, 2012, 2014; Barnett, 2005), I am suggesting that they can complement and reinforce each other. What Marxism lacks - and what Foucauldians provide - is an understanding of the specificity of neoliberal subject positions and their constitution through everyday (often bureaucratic) practices. Conversely, Foucauldians are blind to the specific interests that benefit from neoliberalism, without acknowledgement of which it is hard to make sense of the dominant trends of the past 40 years. $^{v}$

Neoliberalism is not merely the revival of laissez-faire or an old form of capitalism but it is still a form of capitalism, and cannot be understood outside of any analysis of the 
history and dynamics of capitalist accumulation. Neoliberalism is not simply destructive, and is rather productive of modes of life and subjectivity - but it is not exhaustive of all possible modes and it does face (sometimes successful) opposition. Neoliberalism is neither monocausal nor the result of a conspiracy - but it has been aggressively pursued by those whom it benefits. Bringing together the Marxist and Foucauldian approaches allows us to analyse both the broader class dimensions of neoliberalism and its operation on the ground: to understand that "neoliberalism equally involves the economy and subjectivity, "work" and "work on the self"' (Lazzarato, 2012: 93). 


\section{Bibliography}

Albo G, Gindin S and Panitch L (2010) In and Out of Crisis: The Global Financial Meltdown and Left Alternatives. Oakland, CA: PM Press.

Barnett C (2005) The consolations of 'neoliberalism'. Geoforum 36(1): 7-12.

Birch K (2015) Neoliberalism: The Ways and Wherefores... and Future Directions. Sociology Compass 9(7): 571-84.

Brenner N, Peck J and Theodore N (2010) Variegated neoliberalization: geographies, modalities, pathways. Global Networks 10(2): 182-222.

Brown W (2005) Edgework: Critical Essays on Knowledge and Politics. Princeton, NJ: Princeton University Press.

Brown W (2015) Undoing the Demos: Neoliberalism's Stealth Revolution. New York, NY: Zone Books.

Burchell G (1996) Liberal government and techniques of the self. In: Barry A, Osborne T and Rose N (eds) Foucault and political reason: Liberalism, neo-liberalism and rationalities of government. London: Routledge.

Callinicos A (2010) Bonfire of Illusions: The Twin Crises of the Liberal World. Cambridge: Polity. 
Clarke J (2008) Living with/in and without neo-liberalism. Focaal 51: 135-147.

Collier SJ (2012) Neoliberalism as big Leviathan, or...? A response to Wacquant and Hilgers. Social Anthropology 20(2): 186-195.

Dardot P and Laval C (2013) The New Way of the World: On Neoliberal Society, trans. Elliott G. London: Verso.

Davies W (2014) Neoliberalism: A Bibliographic Review. Theory, Culture \& Society 31(7/8): 309-317.

Dean M (2015) Foucault Must Not Be Defended. History and Theory 54: 389-403.

Duménil G and Lévy D (2004) Capital Resurgent: Roots of the Neoliberal Revolution, trans. Jeffers D. Cambridge, MA: Harvard University Press.

Duménil G and Lévy D (2011) The Crisis of Neoliberalism. Cambridge, MA: Harvard University Press.

Ferguson J (2010) The Uses of Neoliberalism. Antipode 41(S1): 166-184.

Flew T (2012) Michel Foucault's The Birth of Biopolitics and contemporary neo-liberalism debates. Thesis Eleven 108(1): 44-65.

Flew T (2014) Six theories of neoliberalism. Thesis Eleven 122(1): 49-71. 
Foucault M (1979) The History of Sexuality Volume One: An Introduction, trans. Hurley R.

London: Allen Lane

Foucault M (1980) Power/Knowledge: Selected Interviews and Other Writings 1972-1977, ed.

Gordon C. New York, NY: Pantheon Books.

Foucault M (2007) Security, Territory, Population: Lectures at the Collège de France, 1977-78, ed. Senellart M, trans. Burchell G. Basingstoke: Palgrave Macmillan.

Foucault M (2008) The Birth of Biopolitics: Lectures at the Collège de France, 1978-79, ed.

Senellart M, trans. Burchell G. Basingstoke: Palgrave Macmillan.

Gordon C (1991) Governmental Rationality: An Introduction. In: Burchell G, Gordon C and Miller P (eds) The Foucault Effect: Studies in Governmentality with Two Lectures by and an Interview with Michel Foucault. Chicago, IL: The University of Chicago Press.

Gordon C (2015) Foucault, neoliberalism etc. Foucault News

https://foucaultnews.com/2015/01/15/colin-gordon-foucault-neoliberalism/ (last accessed 21 December 2017).

Glyn A (2006) Capitalism Unleashed: Finance, Globalization and Welfare. Oxford: Oxford University Press.

Hall S (2011) The Neo-Liberal Revolution. Cultural Studies 25(6): 705-728.

Harvey D (2005) A Brief History of Neoliberalism. Oxford: Oxford University Press. 
Hibou B (2015) The Bureaucratization of the World in the Neoliberal Era: An International and Comparative Perspective, trans. Brown A. New York, NY: Palgrave Macmillan.

Hilgers M (2013) Embodying neoliberalism: thoughts and responses to critics. Social Anthropology 21(1): 75-89.

Jessop B (2013) Putting neoliberalism in its time and place: a response to the debate. Social Anthropology 21(1): 65-74.

Kotz DM (2015) The Rise and Fall of Neoliberal Capitalism. Cambridge, MA: Harvard University Press.

Larner W (2000) Neo-liberalism: Policy, Ideology, Governmentality. Studies in Political Economy 63: 5-25.

Lazzarato M (2012) The Making of the Indebted Man. Los Angeles, CA: Semiotext(e).

McNay L (1994) Foucault: A Critical Introduction. Cambridge: Polity Press.

McNay L (2009) Self as Enterprise: Dilemmas of Control and Resistance in Foucault's The Birth of Biopolitics. Theory, Culture \& Society 26(6): 55-77.

Mirowski P (2014) Never Let a Serious Crisis Go to Waste: How Neoliberalism Survived the Financial Meltdown. London: Verso. 
Ong A (2006) Neoliberalism as Exception: Mutations in Citizenship and Sovereignty. Durham, NC: Duke University Press.

Peck J (2010) Constructions of Neoliberal Reason. Oxford: Oxford University Press.

Peck J and Tickell A (2002) Neoliberalizing Space. Antipode 34(3): 380-404.

Smith A (1976) An Inquiry into the Nature and Causes of the Wealth of Nations, 2 vols.

Oxford: Clarendon Press.

Springer S (2012) Neoliberalism as discourse: between Foucauldian political economy and Marxian poststructuralism. Critical Discourse Studies 9(2): 133-147.

Van Apeldoorn B and Overbeek H (2012) Introduction: The Life Course of the Neoliberal Project and the Global Crisis. In: Overbeek H and Van Apeldoorn B (eds) Neoliberalism in Crisis. Basingstoke: Palgrave Macmillan.

Venugopal R (2015) Neoliberalism as concept. Economy and Society 44(2): 165-187.

Wacquant L (2012) Three steps to a historical anthropology of actually existing neoliberalism. Social Anthropology 20(1): 66-79. 
' In this sense, they differ from much of the recent work on Foucault and neoliberalism, which has tended to restrict itself to textual commentary on and interpretation of The Birth of Biopolitics or to debates over Foucault's own relationship to neoliberalism.

ii Given the ways in which I have circumscribed the 'Marxist' and 'Foucauldian' approaches, I am not going to engage directly with a similar debate that has recently taken place within and across the disciplines of anthropology, geography, and urban studies. On one side of this debate have been those, informed by Marxist and neo-Marxist theories, who advocate a 'structuralist' or 'systemic' approach (e.g. Peck and Tickell, 2002; Jessop, 2013) or who explore the role of neoliberal thinktanks as 'organic intellectuals' whose ideas are constructed and operate within particular conjunctural conditions (e.g. Peck, 2010). On the other side are those who support a 'governmentality' approach inspired by Foucault (e.g. Ong, 2006; Collier, 2012). Also contributing to the debate are those searching (in different ways) for a 'third way' (e.g. Hilgers, 2013; Wacquant, 2012; Larner, 2000; Springer, 2012) and those who question the efficacy or utility of 'neoliberalism' as a critical concept. This debate has generated some genuine insights - the most sophisticated contribution is that of Brenner et al. (2010) - but the positions taken are not those which I analyse in this article. Although the 'structuralist' side emphasise the global dominance or hegemony of neoliberalism as well as its uneven and contradictory development, they downplay or ignore the central feature of the Marxist approach that I analyse, namely the claim that neoliberalism is a class project. The 'governmentality' side, on the other hand, has a sometimes loose relation to Foucault's work, instead resorting to generic poststructuralist themes of fluidity, mobility, complexity, hybridity, and indeterminacy.

iii Although Mirowski's attempts at 'teasing out the operation of [neoliberal] power on the ground and under the skin' (Mirowski, 2014: 97) resonate with Foucauldian analyses - in that he views neoliberalism in non-Marxist terms as a state-led project that reconfigures the market and constitutes new (entrepreneurial) subjects - he is much more critical of Foucault than the other thinkers considered here, and hence I do not here categorise him as a 'Foucauldian'. 
iv See Dean (2015) and Gordon (2015) for convincing critiques of the claim that Foucault himself was some kind of neoliberal.

${ }^{\vee}$ There are of course different ways in which Marxist and Foucauldian approaches might be combined. Indeed, notwithstanding her broadly Foucauldian framework - and the associated weaknesses identified above - Wendy Brown herself calls for something like a Marxist-Foucauldian approach. She does so, however, by suggesting that Foucault might be 'welded' to the analysis of capitalism offered by Marx rather than the analyses of neoliberalism offered by Marxists (and which she rather contrasts unfavourably with Foucault): as such, she has little to say about the key elements of the Marxist analyses of neoliberalism that I wish to foreground in my own synthesis of Marxism and Foucault, in particular its class dimension (Brown, 2015: 77). 